Ethiopian Journal of Environmental Studies \& Management 7 Suppl.: 870 - 880, 2014.

ISSN:1998-0507

doi: http://dx.doi.org/10.4314/ejesm.v7i2.7S

Submitted: October 09, 2014

Accepted: December 02, 2014

\title{
FINANCIAL FEASIBILITY OF TRADITIONAL SMALL-SCALE BRICK-MAKING ENTERPRISES IN SOUTHEAST SULAWESI, INDONESIA
}

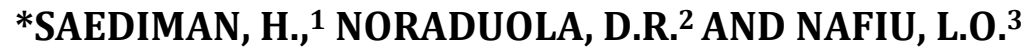 \\ ${ }^{1}$ Faculty of Agriculture, Halu Oleo University, Kampus Bumi Tridarma Anduonohu, Kendari \\ 93232 Indonesia \\ ${ }^{2}$ Faculty of Engineering, Halu Oleo University, Kampus Bumi Tridarma Anduonohu, Kendari \\ 93232 Indonesia \\ ${ }^{3}$ Faculty of Livestock Sciences, Halu Oleo University, Kampus Bumi Tridarma Anduonohu, \\ Kendari 93232 Indonesia
}

\begin{abstract}
This study aimed to assess financial feasibility of traditional small-scale brick-making enterprises in Southeast Sulawesi, Indonesia. Data were collected from ten units of brick enterprises using interview method based on the questionnaire. Based on data and information obtained, assumptions for the analysis were established. Data were analyzed using financial tools of decision making, namely NPV, IRR, BCR, PBP, and sensitivity analysis. The study revealed that the enterprises can generate a positive NPV, IRR higher than the discount rate, BCR higher than 1 , and PBP shorter than economic life of the project. These results indicated that small-scale brick production is financially feasible, and from the business prospect viewpoint, the enterprises that received microcredit from local commercial bank could repay fully principal and interest repayment of the loan. Banks are recommended to proactively provide loans to help brick producers get funds for their brick-making activities. Increased access to capital from banks will strengthen their bargaining power, increase their income, and improve their lives. In view of the present use of outdated technologies, the government and all stakeholders need to study and take efforts to encourage the use of other alternative technologies with higher energy efficiency and reduced air pollution.
\end{abstract}

\section{Introduction}

Fired clay brick is one of the most important building materials in Indonesia. Along with the increased economic growth of the country, the demand for bricks by the construction sector increased steadily. Such increased demand is also encouraged by the fact that people prefer houses made of stone instead of wood. This condition creates an opportunity for the establishment of brickmaking enterprises. Therefore, brick-making industries can be found in all regions in Indonesia with the majority of brick kilns located as clusters in peri-urban and rural areas. It is mainly done in small-scale and has become source of livelihood which can provide employment, household income, and multiplier effect to the economy of the surrounding areas (Rochman, 2005; Buyinza et al., 2009).

In addition to the demand factor, the widespread operation of brick-making is related to the low investment capital needed and availability of raw clay. For the traditional brick-making, the major investment cost is for the construction of

*Corresponding Author: Saediman, H. 
bangsal (shed), whereas equipment needed only consist of hoe, wooden mould, and bucket, which can be made and repaired within the local community. Raw materials consist of raw clay, water, and other mixture materials (if needed), and firewood during firing. The process of brick-making is quite simple which anyone can easily learn and practise.

Brick-making is one of small-scale artisanal businesses which have long been done by people in Southeast Sulawesi. One of the production centers is Langge village in Ranomeeto subdistrict of South Konawe District. Brick-making has been developing well in the area because (i) there is enough land for brick production, (ii) it is close to Kendari City, the capital of the province, where demand for bricks is high, (iii) the sites are level or nearly so, and (iv) the sites have relatively enough water supply. However, brick-making enterprises are operating in the informal sector with very limited government involvement. Absence of government regulation means the industry has potential role in deforestation and greenhouse gas emission (Alam, 2006), but this is beyond the scope of the present study.

Accessibility to the sites was poor, especially during rainy season, making it difficult for trucks to deliver firewood and collecting bricks. Poor accessibility also led to low value of land and reluctance of banks to provide lending as visiting and monitoring was difficult. Brick production took place in small units, using manual labor, sun drying and traditional firing technologies. Bricks producers generally lacked technical, managerial and marketing skills. They were also generally weak in terms of mentality, education, motivation in exploring opportunities, access to technology and capital (Tarmidi, 2005; Saediman et al., 2006).
The main motivation for the present research arose from the low economic wellbeing of the majority of producers and workers in the brick-making industry. It was found from a preliminary survey that the industry only benefited a few of them who had already much capital and were involved in brick marketing as collectors or intermediaries. The major issue was that producers lack capital especially during the firing stage when they needed fund to buy firewood. Therefore, they borrowed money from money lenders or pre-sold the bricks (FAO, 1993), both with the implication of low price of the bricks they produced. Bank schemes actually existed to assist the small sector, but they had no access to such schemes because of having no collateral, poor book-keeping practices, and perceived complicated procedures at banks (Saediman et al., 2006). Similar to observations in India (UNDP-GEF, 2010a) and Bangladesh (UNDP, 2010b), banks in the study province had limited experience with brick Micro and Small Scale Enterprises (MSEs); they lacked interaction with, and appeared not to have sufficient understanding of, the brick-making operations, especially its feasibility. As a result, banks were hesitant to make loans to the brick industry. Lack of access to financial institution and negative implication of borrowing to informal money lenders are closely related to the low economic wellbeing of bricks producers.

In the context of increasing access to financing from formal financial institutions such as banks, as well as provision of assistance to economically viable MSEs, comprehensive understanding of feasibility of brick-making is very much needed. Reliable information on the feasibility of brick production will provide necessary confidence to banks to give loans to brick producers, and even to develop financial products that best suit to brick-making 
characteristics (Lopez et al., 2012). Brick producers can use such information to develop their existing businesses or to start new investment, whereas local government can seize the opportunities of developing brick-making through training, technical assistance, and policy support. With this background in mind, the present study was conducted to analyze the feasibility of smallscale brick-making enterprises.

\section{Methodology \\ Study Site}

The study was conducted in November 2010 in Langge village, Ranomeeto subdistrict, South Konawe District, Southeast

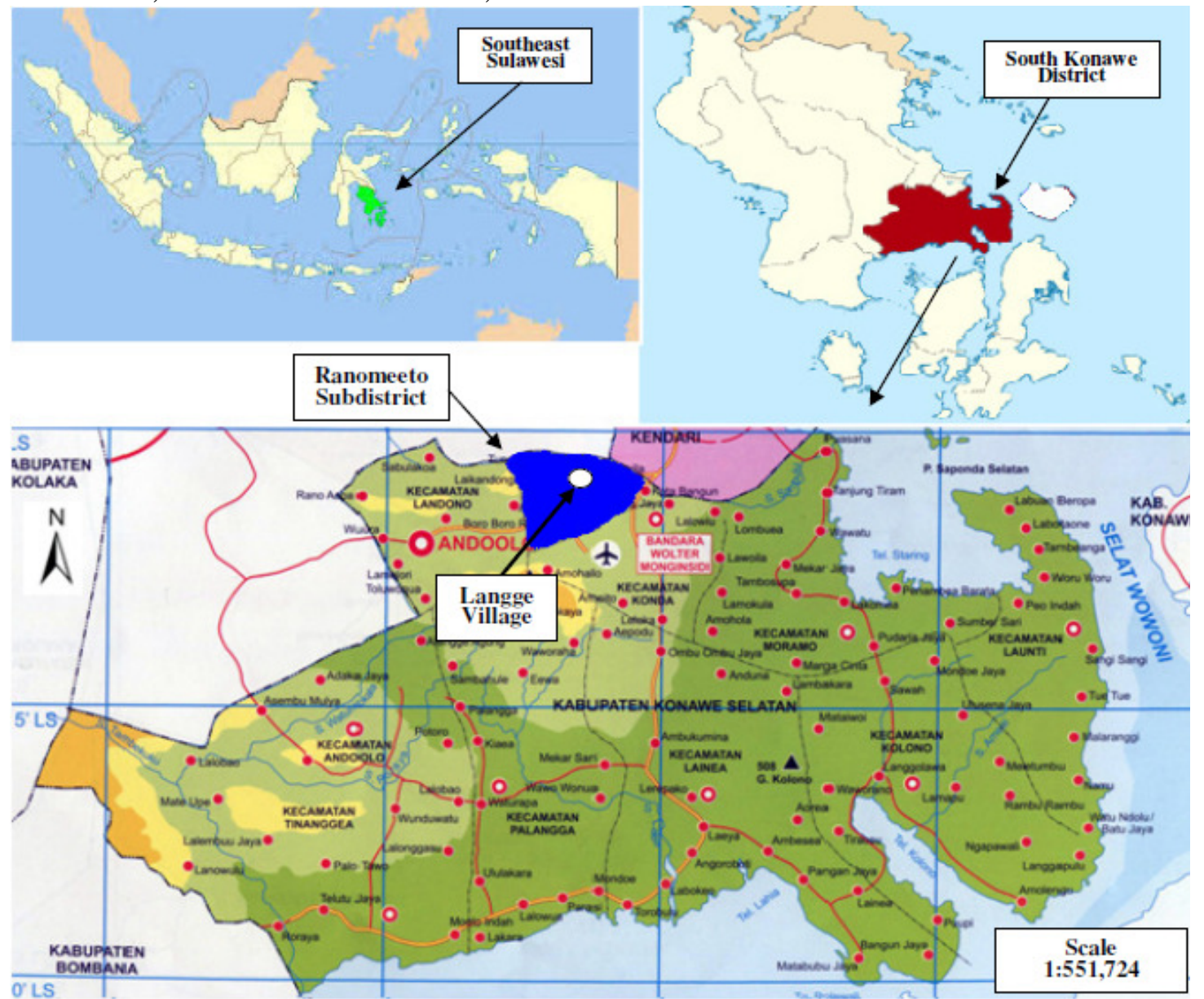

Source: adapted from wikipedia.org and kendari.bpk.go.id Figure 1: Map of Study Area
Sulawesi province (Figure 1). South Konawe is situated between $3^{\circ} 59^{\prime}$ and $4^{\circ} 32^{\prime}$ south latitude, and $121^{\circ} 58^{\prime}$ and $123^{\circ} 16^{\prime}$ east longitude. The village is located 10 kilometers from Kendari, the capital of the province. The population of the village was 2,288 in 2013. It has an area of $2.64 \mathrm{~km}^{2}$ with mean rainfall of $2,053 \mathrm{~mm}^{3}$. Temperatures range between 27 and $31^{\circ} \mathrm{C}$ throughout the year. According to official record from the village, the number of brick-making units in the village was 332 in 2013, or $75 \%$ from the total number of brick-making units in the subdistrict. 


\section{Data Collection}

Data and information were collected using interview method based on the questionnaire. Ten brick-making units were selected purposively as respondents. Data collected included investment, labor, production process, market, and government involvement. Interviews were done with brick producers and workers in the selected brick-making enterprises supported by direct observation of the production process in the shed and brick clamp. Data and information obtained were used first to establish assumptions for the analysis related to parameters of production process, technology, and costs (Table 1). These assumptions were established based on observation in the field and discussions with bricks producers and workers.

Table 1: Asumptions Used in the Analysis of Financial Feasibility of Brick-making

\begin{tabular}{l|lll}
\hline No. & Asumption & Unit & Value or Total \\
\hline 1 & Length of project life & Year & 4 \\
& Length of one production cycle & Day & 50 days \\
& Number of production cycles in a year & Times & 6 \\
\hline 2 & Technical indicator & & \\
& Brick size & $\mathrm{cm}^{3}$ & $5 \times 10 \times 20$ \\
& Percentage of breakage & $\%$ & 1 \\
\hline 3 & Business scale & $\mathrm{m}^{3}$ & 20 \\
& $\begin{array}{l}\text { a. Production capacity per cycle } \\
\text { b. Number of brick shed }\end{array}$ & Unit & 1 \\
& $\begin{array}{l}\text { c. Size of brick shed } \\
\text { d. Economic life of brick shed }\end{array}$ & Year & 4 \\
& e. Cost of brick shed construction & US\$ & 567 \\
\hline 4 & Labor & Person & 3 \\
& $\begin{array}{l}\text { a. Number of workers } \\
\text { b. Family labors }\end{array}$ & Person & 2 \\
& c. Paid labor & Person & 1 \\
\hline 5 & Source of capital & & \\
& a. Proportion of capital from bank credit and & $\%$ & $70: 30$ \\
& own fund & & 2 \\
& b. Period of credit for investment capital & Year & 1 \\
\hline
\end{tabular}

\section{Data Analysis}

The costs incurred in brick-making and benefits received from the final product were calculated after the data were collected in the field. To estimate unit production costs, the methodological framework followed consisted of (i) the determination of the quantities of various inputs used in the brickmaking process, and (ii) the estimation of costs for each input, and that of the unit production cost (FAO-WEP, 1984). The calculations were done at $22 \%$ discount interest rate. To determine the investment feasibility on brick-making enterprise, four financial tools of decision making, namely Net Present Value (NPV), Benefit-Cost Ratio (BCR), Internal Rate of Return (IRR) and Pay Back Period (PBP) were applied. Sensitivity analysis was also carried out to assess the economic viability of brick production.

(i) NPV is the algebraic sum of the discounted costs and revenues at a specified 
interest rate. An investment is acceptable if the NPV is positive and is not acceptable if it is negative.

$$
N P V=\sum_{1}^{t} \frac{B_{t}-C_{t}}{(1+i)^{t}}
$$

Where:

NPV $=$ Net Present Value

$\mathrm{Bt}=$ Revenues or positive cash flows in year $\mathrm{t}$

$\mathrm{Ct}=$ Costs or negative cash flows in year $\mathrm{t}$

$\mathrm{t}=$ year in which the cash flow occurs

$\mathrm{i}=$ interest rate

(ii) BCR: It is computed as the present value of benefits divided by the present value of costs as follows:

$$
B C R=\frac{\sum_{1}^{t} B_{t}(1+i)^{t}}{\sum_{1}^{t} C_{t}(1+i)^{t}}
$$

If the ratio is greater than one, the project is yielding more benefits than its costs. Investment is accepted is the BCR exceeds 1 and is not accepted if it is less than 1 .

(iii) IRR: it is the discount rate that makes the net present value equals to zero. Hence, IRR is the interest rate equalizes the present value of costs and revenues. The higher the IRR, the more desirable project becomes.

$$
I R R=i_{1}+\left(i_{2}-i_{1}\right) \times \frac{N P V_{1}}{\left(N P V_{2}-N P V_{1}\right)}
$$

Where:

IRR = internal rate or return

$\mathrm{i}_{1}=$ discount rate 1

$\mathrm{i}_{2}=$ discount rate 2

$\mathrm{NPV}_{1}=$ Net Present Value at discount rate 1

$\mathrm{NPV}_{2}=$ Net Present Value at discount rate 2

(iv) BEP: It is the point at which cost and revenue are equal: the producer or the enterprise generates neither a profit nor a loss on operating activities. BEP in units is calculated by dividing the BEP in sales dollar by the selling price of output. BEP in sales dollar was calculated using the following formula:
Break Even Point $(\mathrm{Rp})=\frac{\text { Fixed Cost }}{\left(1-\frac{\text { Total Variable Cost })}{\text { Total Revenue }}\right)}$

(v) Pay Back Period (PBP): This is used to estimate the time needed to yield return that would cover investment and capital spent. The project or activity is feasible if PBP is less than the economic life of the project. If PBP is more than the economic life of the project, the project is not feasible.

$$
\mathrm{PBP}=\frac{\text { Investment }}{\text { Net annual cash flow }}
$$

\section{Results and Discussions Investment Costs}

Investment costs needed to establish brickmaking enterprise consist of costs for purchasing land, building brick shed, buying tools, and obtaining village governmental permit. All these investment costs should be expended at the year 0 before starting the business. Total investment cost is $\$ 2,006.7$. Of this amount the greatest proportion is for purchasing land and building shed, accounting for $96.1 \%$ of the total investment.

Table 2: Details of Costs for Investment

\begin{tabular}{llll}
\hline No & Item & Cost & \\
\cline { 3 - 4 } & & US\$ & $\%$ \\
\hline 1 & Village permits & 8.5 & 0.4 \\
2 & Land and brick shed & $1,927.9$ & 96.1 \\
3 & Tools & 70.3 & 3.5 \\
& Total investment & $2,006.7$ & 100.0 \\
\hline
\end{tabular}

\section{Operational Costs}

Operational costs consist of variable and fixed costs. Variable costs consist of costs for raw material, supporting materials, and labor. Fixed costs include costs for electricity, telephone, water, moulds, and shovel. Total operational costs per year amounted to $\$ 2,957.4$ consisting of variable cost $\$ 2,891.8$ and fixed cost $\$ 65.5$. 
The details of start-up working capital can be seen in Table 3. The amount of initial working capital would cover costs for two months, namely $\$ 509.5$. The highest component was variable costs amounting to $94.6 \%$ from the total start-up cost.

Table 3: Start-Up Working Capital Needed for One Production Cycle

\begin{tabular}{lll}
\hline No & Cost Components & Value (US\$) \\
\hline A & Variable cost & 482.0 \\
1 & Raw material (clay) & - \\
2 & Supporting materials & 147.4 \\
3 & Labor cost & 328.9 \\
4 & Promotional and marketing costs & 5.7 \\
B & Fixed cost & 27.6 \\
1 & Electricity, telephone and water & 13.6 \\
2 & Implements consumable in a year & 11.3 \\
3 & Miscelaneous costs (10\%) & 2.6 \\
& Total & 509.5 \\
\hline
\end{tabular}

In the study area, clay was the only raw material for brick-making; it was not yet mixed with other substances such as rice husks, bagasse, sawdust, and cow-dung as has been practiced in other areas (Schilderman and Mason, 2009; Siregar, 2010). Because clay was obtained from own land (which had been purchased at the beginning), there was no raw material cost.
At the same time, supporting materials consisted of firewoods and sand.

\section{Source of Capital and Its Repayment}

In this study it was assumed that the fund required to start brick-making enterprise was obtained from bank credit and own fund with the proportion of 70:30. Overall, the amount of fund needed was $\$ 2,516.3$ which was derived from BRI bank $\$ 1,761.4$ and own capital \$754.9 (Table 4).

Tabel 4: Component and Structure of Brick Production Costs

\begin{tabular}{llll}
\hline No & Cost Item & Percentage & Amount (US\$) \\
\hline 1 & Investment cost & & $2,006.7$ \\
& - From bank credit & $70 \%$ & $1,404.7$ \\
& - From own fund & $30 \%$ & 602.0 \\
2 & Working capital & & 509.5 \\
& - From bank credit & $70 \%$ & 536.7 \\
& - From own capital & $30 \%$ & 152.9 \\
3 & Total cost & & \\
& - From bank credit & $70 \%$ & $1,761.4$ \\
& - From own capital & $30 \%$ & 754.9 \\
& Total cost & & $2,516.3$ \\
\hline
\end{tabular}

Calculation of interest rate was based on that of KUR credit program at Bank Rakyat Indonesia in Kendari, namely $22 \%$ p.a. flat interest rate for the loan up to Rp20 million $(\$ 2,268)$, and $14 \%$ p.a. effective interest rate for the loan of Rp21 million-Rp100 million
$(\$ 2,382-\$ 11,340)$. Because the amout of loan taken was less than $\$ 2,268$, the interest charged was $22 \%$ p.a. on flat rate basis for both loans for investment and working capital.

Investment credit was received at the year 0 with the loan tenor of two years, whereas 
microcredit for working capital was received with the loan tenor of one year. Repayment was on monthly basis, consisting of principal and interest repayment on flat rate basis. As shown in Table 5, principal repayment in the year 1 accounted for $\$ 1,059$, consisting of investment credit $\$ 702.3$ and working capital
$\$ 356.7$. In the year 2, principal repayment is only for investment credit $\$ 702.3$. There were also interest repayments each month, so the total repayments in year 1 was $\$ 1,446.5$ and in year $2 \$ 1,434.4$. Both loans were fully repaid at the end of year 2 .

Table 5: Calculation of Credit Repayment (\$) per Year

\begin{tabular}{llllll}
\hline Year & $\begin{array}{l}\text { Principal } \\
\text { Repayment }\end{array}$ & $\begin{array}{l}\text { Interest } \\
\text { Repayment }\end{array}$ & $\begin{array}{l}\text { Total } \\
\text { Repayment }\end{array}$ & $\begin{array}{l}\text { Beginning } \\
\text { Balance }\end{array}$ & $\begin{array}{l}\text { Final } \\
\text { Balance }\end{array}$ \\
\hline Year 0 & & & & $1,761.4$ & $1,761.4$ \\
Year 1 & $1,059.0$ & 387.5 & $1,446.5$ & $1,761.4$ & 702.3 \\
Year 2 & 702.3 & 309.0 & $1,434.4$ & 702.3 & 0 \\
\hline
\end{tabular}

\section{Costs, Revenues, and Break Even Point}

The average number of bricks produced was $20 \mathrm{~m}^{3}$ per production cycle of 50 days. With the breakage level of $1 \%$ and the bricks price of $\$ 37.4$ per $\mathrm{m}^{3}$, the revenue per production cycle was $\$ 741.0$. With the assumption of five production cycles $(83 \%)$ in the year 1 , the total revenue from the sales of bricks was $\$ 3,690.1$. The annual amount of sales in the year 2,3 , and 4 was $\$ 4,445.9$.

Table 6 presents production costs, revenues, and BEP each year during the fouryear project period. Brick-making enterprise is profitable in the year 1 with production capacity of $83 \%$. Net profit in the year 1 is $\$ 577.9$ and profit on sales $15.7 \%$. Taking into account sales, variable cost, and fixed cost, BEP is obtained at the level of $\$ 1,745.0$ or equivalent with $46.6 \mathrm{~m}^{3}$ of bricks. In the year 2 with production capacity of $100 \%$, profit is $\$ 859.7$ with profit on sales $19.3 \%$ and BEP $\$ 1,552.4\left(41.5 \mathrm{~m}^{3}\right)$. In the year 3 and year 4 , the profit and profit on sales increase and BEP improves because there is no longer credit repayment. In average, for the four year period, annual profit was $\$ 920.6$, profit on sales $21.4 \%$, and BEP $\$ 1,158.5$ or equivalent to $31.0 \mathrm{~m}^{3}$ of red bricks.

Table 6: Estimated Production Cost and Revenue (\$) and BEP Each Year

\begin{tabular}{lllllll}
\hline No & Description & \multicolumn{3}{c}{ Year } & Average \\
\cline { 3 - 6 } & & 1 & 2 & 3 & 4 & \\
\hline 1 & Total Revenue & $3,690.1$ & $4,445.9$ & $4,445.9$ & $4,445.9$ & $4,445.9$ \\
2 & Total Cost & $3,010.2$ & $3,434.5$ & $3,125.4$ & $3,125.4$ & $3,173.9$ \\
3 & Gross Revenue & 679.9 & $1,011.5$ & $1,320.5$ & $1,320.5$ & $1,083.1$ \\
4 & Tax (15\%) & 102.0 & 151.7 & 198.1 & 198.1 & 162.5 \\
5 & Income & 577.9 & 859.7 & $1,122.4$ & $1,122.4$ & 920.6 \\
6 & Profit On Sale & 15.7 & 19.3 & 25.2 & 25.2 & 21.4 \\
7 & BEP in US\$ & $1,745.0$ & $1,552.4$ & 668.3 & 668.3 & $1,158.5$ \\
& BEP in Unit $\left(\mathrm{m}^{3}\right)$ & 46.6 & 41.5 & 17.9 & 17.9 & 31.0 \\
\hline
\end{tabular}

$\mathrm{BEP}$ is one of the most common tools used in evaluating the economic feasibility of an enterprise or product. Break-even units indicate the level of sales that are required to cover costs, whereas break-even sales indicate the dollar of gross sales required to break-even (Horhota, 2009). As shown in Table 6, BEP in dollar sales and in unit sales every year are above their break-even figures and result in profit, even in the year 1 when 
many new enterprises and products operate at a loss. This indicates that brick-making enterprise in the study area is profitable.

\section{Financial Feasibility of Brick-Making}

Table 7 reveals the investment criteria of the brick-making enterprise. At the discounted rate of $22 \%$ per year during the period of four years, NPV is positive $(>0)$, IRR higher than the interest rate at local commercial bank, BCR higher than 1, and PBP shorter than the life of the project. The results of all these investment criteria confirm that brick-making enterprise is financially feasible. Satisfactory financial feasibility means that, if seen from the prospect of brick-making business, producers could fully and timely repay the microcredit taken from commercial banks.

Table 7: Financial Feasibility Indicator of Brick-Making

\begin{tabular}{lll}
\hline Investment Criteria & Value & Justification \\
\hline NPV & $\$ 1,710$ & $>0$ \\
IRR & $57.69 \%$ & $>22 \%$ \\
BCR & 1.85 & $>1$ \\
PBP & 2.40 years & $<4$ years \\
\hline
\end{tabular}

Satisfactory results of financial analysis of brick-making as per findings of this study are in line with results of many studies. For example, Reid (1989) reported financially feasible operation of artisan brick production in South Africa. Rozemuller (1999) found out that brick-making enterprises in North West Cambodia were in financially healthy position. Sianturi (2013) investigated brickmaking industries in North Sumatera of Indonesia and concluded that with RC Ratio of 1.2, brick-making production was profitable. Proposed artisan brick-making production in Uganda (World Bank, 1989) and in Indonesia (World Bank, 1987) also resulted in satisfactory financial rate of return.

\section{Sensitivity Analysis}

As a project is subject to a variety of risks in the longer period of time, a sensivity analysis was conducted to check for the changes in the decision criterion due to possible changes in input and output sides of the investment (Duguma, 2013). In this regard, the following three scenarios were applied: (i) decrease in revenue (Scenario 1), (ii) increase in variable cost (Scenario 2), and (iii) simultaneous increase in variable cost and decrease in revenue (Scenario 3),

Table 8 shows the results of sensitivity analysis under the three scenarios. With the Scenario 1, where revenue drops $10 \%$ due to decrease in the volume of output sold or decrease in the price of output, all investment criteria (NPV, IRR, BCR, and PBP) indicates that brick-making business is financially feasible. Likewise, with the $10 \%$ increase in variable costunder Scenario 2, brick-making business is also financially feasible. However, the financial performance in Scenario 2 is better than that in Scenario 1, implying that brick-making business is more sensitive to the changes in revenue (due to changes in the volume of output sold or decrease in the price of output) than to the changes in variable cost (due to increase in labor cost or price of raw materials). Simultaneous 9\% decrease in revenue and $9 \%$ increase in variable cost result in the investment criteria still being feasible. When revenue decreases $10 \%$ and at the same time variable cost increases $10 \%$, NPV becomes negative, IRR less than prevailing interest rate, $\mathrm{BCR}$ less than 1 , and $\mathrm{PBP}$ more than the period of the project. At this point, brickmaking business becomes unfeasible. 
Tabel 8: Sensitivity Analysis of Brick-making Enterprises under Three Scenarios

\begin{tabular}{llllll}
\hline $\begin{array}{l}\text { Investment } \begin{array}{l}\text { Scenario } \\
\text { Criteria }\end{array} \\
\text { Decrease in Revenue }\end{array}$ & $\begin{array}{l}\text { Scenario 2: 10\% Increase } \\
\text { in Variable Cost }\end{array}$ & $\begin{array}{l}\text { Simultaneous Decrease in Revenue } \\
\text { and Increase in Variable Cost }\end{array}$ \\
\hline NPV & $\$ 663.3$ & $\$ 1,029.2$ & $\$ 155.3$ & $10 \%$ \\
IRR & $36.2 \%$ & $43.8 \%$ & $25.36 \%$ & $(\$ 17.5)$ \\
BCR & 1.33 & 1.51 & 1.08 & 0.99 \\
PBP & 3.46 year & 3.15 year & 3.99 year & $>4$ \\
\hline
\end{tabular}

The results of analysis of financial tools described above showed that small-scale brick-making is profitable and financially feasible, implying that it is possible to provide loans to brick-making enterprises and achieve full and timely repayments. In fact, for brick-making enterprises currently operating, they only need working capital to meet costs for certain activities such as to buy firewood for firing bricks and to pay for the cost of paid labors. Thus the prospect of their business should actually be even better. However, the lack of working capital often forces producers to borrow money from money lenders, pre-sell the bricks, or produce on order only. In all cases their production costs are higher than those who do not face the same problems (FAO, 1999). In the study village, from the price of bricks of $\$ 37.4$ per $\mathrm{m}^{3}$, producers who pre-sold their bricks could only get $\$ 28.4$ per $\mathrm{m}^{3}$, which is a reduction of $24 \%$ from the normal price. Therefore, brickmaking is more profitable for producers who have their own resources. As mentioned by FAO (1999), for most small-scale bricks producers, especially those who have problem obtaining working capital, brickmaking appears to be a marginal business. This again confirms the need for formal financial institutions to provide microcredit to bricks producers, as it will increase the amount of income they will get from brickmaking leading to their more improved lives.

\section{Conclusion}

This paper investigates the financial feasibility of small-scale brick-making production in Southeast Sulawesi Province, Indonesia. It was assumed that a smallscale brick-making enterprise would take microcredit from a commercial bank to cover $70 \%$ of the total cost needed, consisting of loans for investment and for working capital. With the interest rate of $22 \%$ per annum on flat basis, the enterprises can repay fully all principal and interest repayments at the end of the year 2. Cash flow analysis shows that the enterprise could generate average annual revenue of $\$ 4,445.9$ and total cost of $\$ 3,173.9$, resulting in an average net cash flow of $\$ 920.6$ per year (after deduction of $15 \%$ tax). The results of financial tool analysis show that the enterprise can generate an NPV of $\$ 1,710$, IRR 57.7\%, BCR 1.85, and PBP 2.4 years. Since NPV is positive, IRR higher than the discount rate, BCR higher than 1, and PBP shorter than economic life of the project, these results indicate that small-scale brick production is feasible.

A sensitivity analysis is performed to ascertain the responsiveness of the NPV and other investment criteria to fluctuations in the revenue and variable cost. The analysis shows that with the $10 \%$ decrease in revenue, or the $10 \%$ increase of variable cost, or simultaneous $9 \%$ decrease in revenue and $9 \%$

increase in variable cost, brick production is still feasible. Given these results, banks are recommended to proactively provide loans to help bricks producers to get funds for their brick-making activities. Increased access to 
capital from formal financial institutions will strengthen their bargaining power, increase their income, and improve their lives. The government can provide support in the form of technical assistance, traning courses, and regulation. In view of the present use of outdated technologies, the government and all stakeholders need to study and take efforts to encourage the use of other alternative technologies with higher energy efficiency and reduced air pollution.

\section{Acknowledgment}

This study was financially supported by Bank of Indonesia Southeast Sulawesi branch. The authors are grateful to Mr A.M. Yusuf for valuable administrative and technical assistance during the research work

\section{References}

Alam, S.A. (2006). Use of Biomass Fuels in the Brick-Making Industries of Sudan: Implications for Deforestation and Greenhouse Gas Emission. MSc Thesis submitted at Department of Forest Ecology, University of Helsinki, Helsinki.

Buyinza, M., Khainza, C. and Bukenya, M. (2009). Emerging Local Economic Dynamics Shaping the Transformation and Use of Wetlands for Brick Making in Goma Sub-County, Mukono District, Uganda. Online Journal of Earth Sciences 3 (1): 23-31

Duguma, L.A (2013). Financial Analysis of Agroforestry Land Uses and Its Implications for Smallholder Farmers Livelihood Improvement in Ethiopia, Agroforestry System, 87: 217-231

FAO (1993). Status and Development Issues of the Brick Industry in Asia. Bangkok.

Horhota, L. (2009). Financial Analysis Techniques Employed in Agriculture. International Conference on Applied Economics.
ILO-WEP (1984). Small-scale Brick-making, ILO, Geneva

Lebbing, B. (1999). Energy Use in SmallScale Brick Making Industries in Northeast Thailand, RWEDP/FAO and Eindhoven University of Technology, Bangkok and Eindhoven.

Lopez, A., Lyoda, N., Segal, R. and Tsai, T. (2012). The Potential for Emissions Reduction and Investment in Efficiency Technologies for the Asian Brick Industry. Washington: Carbon War Room.

Reid, M.C. (1989). A Mineral Economic Feasibility of Artisan Brickworks. Unpublished M.Com Thesis. Faculty of Economics and Management Sciences. Rand Afrikaans University. Retrieved on 6 June 2014 from https://ujdigispace.uj.ac.za

Rochman, H. (2005). Persebaran dan Daya Serap Tenaga Kerja Industri Rumah Tangga Batu Bata di Desa Baran Kecamatan Ambarawa Kabupaten Semarang. Unpublished B.A. Thesis. Fakultas Ilmu Sosial, Universitas Pendidikan Semarang.

Rozemuller, B. (1999). An Overview of the Brick and Tile Manufacturing Industry in North West Cambodia, UNDP/CARERE, Phnom Penh.

Saediman, H., Madiki, A., Nafiu, L.O. and Safilu, L. (2006). Mapping Study of Micro, Small and Medium Scale Enterprises in Southeast Sulawesi Province. Kendari: Bank of Indonesia Southeast Sulawesi Office.

Schilderman, T, and Mason, K. (2009). Using Residues as Fuel in Small-Scale Brickmaking, Proceedings of the $11^{\text {th }}$ International Conference on Nonconventional Materials and Technologies 6-9 September 2009, Bath, U.K. Sianturi, R.N.S. (2013). Analisa Pengolahan Batu Bata di 
Kabupaten Deli Serdang: Studi Kasus di Desa Tanjung Mulia Kecamatan Pagar Merbau. Unpublished B.Sc Thesis. Fakultas Pertanian. Universitas Sumatera Utara, Medan.

Siregar, N. (2010). Pemanfaatan Abu Pembakaran Ampas Tebu dan Tanah Liat pada Pembuatan Batu Bata. Unpublished B.Sc Thesis. Faculty of Mathematics and Natural Sciences. Universitas Sumatera Utara, Medan.

Tarmidi, L.T. (2005). The Importance of MSEs in Economic Development of Developing APEC Countries. Paper presented at the APEC Study Center Consortium Conference in Jeju Korea, 22-25 May 2005.

UNDP-GEF. (2010a). Energy Efficiency Improvements in the Indian Brick Industry - Project Document.

UNDP-GEF. (2010b). Improving Kiln Eficiency in the Brick Making Industry - Project Document.
World Bank (1987). Indonesia - Energy efficiency improvement in the brick, tile and lime industries on Java. Activity completion report; no. ESM 6787. Energy Sector Management Assistance Programme. Washington, DC: World Bank. http://documents.worldbank.org/ curated/en/1987/03/700751/indonesiaenergy-efficiency-improvement-bricktile-lime-industries-java

World Bank (1989). Uganda - Energy efficiency improvement in the brick and tile industry. Activity completion report ; no. ESM 97 89. Energy Sector Management Assistance Programme. Washington, DC: World Bank. http://documents.worldbank.org/ curated/en/1989/03/ 441812/ugandaenergy-efficiency-improvement-bricktile-industry 